\title{
Hypothermic Machine Preservation of the Liver: State of the Art
}

\author{
Andrea Schlegel $^{1,2} \cdot$ Xavier Muller $^{3} \cdot$ Philipp Dutkowski $^{3}$ \\ Published online: 22 January 2018 \\ (C) The Author(s) 2018. This article is an open access publication
}

\begin{abstract}
Purpose of Review In this review, we highlight which livers may benefit from additional treatment before implantation and describe the concept of hypothermic machine liver perfusion. Furthermore, we explain why cold oxygenated perfusion concepts could potentially lead to a breakthrough in this challenging field of transplantation. Accordingly, we summarize recent clinical applications of different hypothermic perfusion approaches.

Recent Findings The impact of end-ischemic, hypothermic liver perfusion in liver transplantation is currently assessed by two multicenter, randomized controlled trials. Recently, new applications of hypothermic perfusion showed promising results and recipients were protected from severe intrahepatic biliary complications, despite the use of very extended criteria grafts including donation after circulatory death livers.

Summary Hypothermic machine liver perfusion is beneficial for high-risk livers and protects recipients from most feared complications. Importantly, such easy approach is currently implemented in several European centers and new markers obtained from perfusate may improve the prediction of liver function in the future.
\end{abstract}

Keywords Machine perfusion $\cdot$ Mitochondria $\cdot$ Hypothermic oxygenated perfusion (HOPE) $\cdot$ Metabolic liver function

\begin{tabular}{|c|c|c|}
\hline \multicolumn{3}{|c|}{ Abbreviations } \\
\hline \multicolumn{2}{|c|}{ ATP } & Adenosine triphosphate \\
\hline \multicolumn{2}{|c|}{ DAMPs } & Danger-associated molecular patterns \\
\hline \multicolumn{2}{|c|}{ DBD } & Donation after brain death \\
\hline \multicolumn{2}{|c|}{ DCD } & Donation after circulatory death \\
\hline \multicolumn{2}{|c|}{ D-HOPE } & Dual hypothermic oxygenated perfusion \\
\hline \multicolumn{2}{|c|}{ DWIT } & Donor warm ischemia time \\
\hline \multicolumn{2}{|c|}{ EAD } & Early allograft dysfunction \\
\hline \multicolumn{2}{|c|}{ EASL } & $\begin{array}{l}\text { The European Association for Study } \\
\text { of the Liver }\end{array}$ \\
\hline \multicolumn{2}{|c|}{ ECD } & Extended criteria donor \\
\hline \multicolumn{3}{|c|}{ HMP } \\
\hline \multicolumn{3}{|c|}{$\begin{array}{l}\text { This article is part of the Topical Collection on Machine Preservation of } \\
\text { the Liver }\end{array}$} \\
\hline 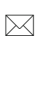 & \multicolumn{2}{|c|}{$\begin{array}{l}\text { Philipp Dutkowski } \\
\text { philipp.dutkowski@usz.ch }\end{array}$} \\
\hline 1 & \multicolumn{2}{|c|}{$\begin{array}{l}\text { The Liver Unit, Queen Elizabeth University Hospital Birmingham, } \\
\text { Birmingham, UK }\end{array}$} \\
\hline 2 & \multicolumn{2}{|c|}{$\begin{array}{l}\text { NIHR Liver Biomedical Research Unit, University Hospitals } \\
\text { Birmingham, Birmingham, UK }\end{array}$} \\
\hline 3 & $\begin{array}{l}\text { Departr } \\
\text { Transpl } \\
\text { CH-80S }\end{array}$ & $\begin{array}{l}\text { af of Surgery \& Transplantation, Swiss HPB and } \\
\text { Center, University Hospital Zurich, Raemistrasse 100, } \\
\text { Zurich, Switzerland }\end{array}$ \\
\hline
\end{tabular}

$\begin{array}{ll}\text { HOPE } & \text { Hypothermic oxygenated perfusion } \\ \text { IC } & \text { Ischemic cholangiopathy } \\ \text { KCs } & \text { Kupffer cells } \\ \text { MELD } & \text { Model of end-stage liver disease } \\ \text { MPT pore } & \begin{array}{l}\text { Mitochondria permeability transition } \\ \text { pore }\end{array} \\ \text { ROS } & \text { Reactive oxygen species } \\ \text { SEC } & \text { Sinusoidal endothelial cells } \\ \text { TLR-4 } & \text { Toll-like-receptor-4 }\end{array}$

\section{Introduction}

The worldwide need of organs for transplantation has triggered a revival of machine perfusion techniques, with the aim to rescue organs previously not considered for transplantation. However, based on the excellent results in conventionally stored non-injured liver grafts $\left[1^{*}\right]$, the aim for machine perfusion in the field appears ambitious; machine perfusion should offer a real repair of high-risk organs before implantation, should also allow testing of organ function, and potentially enable prolonged preservation, if needed for logistic reasons [2]. At the same time, machine perfusion procedures need to be most practical and also affordable. To meet such challenges, an extensive understanding of the underlying 
mechanism of liver injury and protection is of utmost importance.

This review focuses therefore on recent developments and research in cold perfusion techniques in liver transplantation. First, we discuss which liver grafts would benefit from perfusion approaches. Next, we highlight pros and cons of cold liver perfusion. Third, we report on new findings regarding mechanism of injury and protection during and after cold liver perfusion. Finally, we provide a clinical outlook and report on current human applications.

\section{Which Livers May Benefit from New Preservation Techniques?}

Before the era of cold storage, perfusion of organs prior to transplantation had already received major interest, as the idea behind was to maintain organ function outside of the human body by supplying oxygen and nutrients [3]. However, cooling with modern preservation solutions offered a very simple and cheap way of keeping an organ transplantable for several hours without severe loss of viability [4]. Nowadays, the limits of static preservations techniques have been recognized and machine perfusion techniques receive significant reinterest for their potential advantages in supporting organ function during preservation [5]. Despite this, cold storage remains an easy and successful preservation technique for normal or ideal liver grafts, actually depicted in results of a recent benchmark study in transplantation of cold stored livers
[1“]. Of note, definitions of extended criteria donor (ECD) livers are somewhat arbitrary and depend on the donation rates and physiology of donors in different countries, e.g., donor age $>60-80$ years, hepatic steatosis $>15-30 \%$, cold storage $>$ 10-12 h [6-11]. Many European centers nowadays routinely face liver offers from donors above 60 years of age, together with significant amount of steatosis in the era of NASH [12, 13]. Based on this, the "normal" liver graft today is often already aged between 60 and 70 years, with significant macrosteatosis up to $15 \%$ and cold ischemia up to $10 \mathrm{~h}[8$, 13-15]. Such data however differ from the USA, underlined by a significantly higher donor risk index (DRI) in Europe [10]. Extended criteria in Europe therefore include livers with a high amount of macrosteatosis ( $>30$ or $>40 \%$ ), prolonged cold ischemia $(>12 \mathrm{~h})$, additional donor warm ischemia (DCD), or a very high donor age ( $>80$ years) (EASL guidelines $[10,14,16])$. Those liver grafts will likewise need optimization before implantation, especially when combined with risky recipients (re-transplantation, high model of end-stage liver disease-MELD score) [17, 18]. Based on the reported literature, liver grafts have been categorized in Table 1 and potential applications of machine perfusion in extended DBD and DCD livers are described.

\section{Why Cold Perfusion?}

The advantages and disadvantages of hypothermia are both caused by decreased cellular metabolism rates due to slowing
Table 1 Transmitted risk in DBD and DCD liver transplantation and suggested preservation method

\begin{tabular}{|c|c|c|}
\hline Risk class & Risk parameter & Suggested preservation \\
\hline Normal graft $=$ ECD graft & $\begin{array}{l}\text {-Donor age up to } 80 \text { years } \\
\text {-Cold ischemia up to } 10 \mathrm{~h} \\
\text {-Macrosteatosis up to } 20 \%\end{array}$ & Standard cold storage \\
\hline Extended ECD & $\begin{array}{l}\text {-Donor age }>80 \text { years } \\
\text {-Cold ischemia }>10-15 \mathrm{~h} \\
\text {-Macrosteatosis }>20 \%\end{array}$ & Machine perfusion recommended \\
\hline “Normal” DCD graft & $\begin{array}{l}\text {-Donor age up to } 60 \text { years } \\
\text {-Functional donor warm ischemia } \\
\text { up to } 20 \mathrm{~min} \\
\text {-Cold ischemia up to } 6 \mathrm{~h} \\
\text {-Macrosteatosis up to } 5 \%\end{array}$ & Standard cold storage \\
\hline Extended DCD graft & $\begin{array}{l}\text {-Donor age }>60-80 \text { years } \\
\text {-Functional donor warm ischemia }>20 \mathrm{~min} \\
\text {-Cold ischemia }>6-8 \mathrm{~h} \\
\text {-Macrosteatosis }>5-20 \%\end{array}$ & Machine perfusion recommended \\
\hline $\begin{array}{l}\text { Overextended DCD graft } \\
\text { ("high Risk") }\end{array}$ & $\begin{array}{l}\text {-Donor age }>80 \text { years } \\
\text {-Functional donor warm ischemia }>30 \text { min } \\
\text {-Cold ischemia }>8 \mathrm{~h} \\
\text {-Macrosteatosis }>20 \%\end{array}$ & Not without machine perfusion \\
\hline
\end{tabular}

Combination of $>2$ of the risk factors in each risk parameter box

$E C D$ extended criteria graft, $D E D$ donation after brain death, $D C D$ donation after circulatory death 
down of enzymatic processes of multiple proteins in the cold. Protective effects of hypothermia have been repeatedly recognized in the past centuries since the time of Hippocrates. For example, Napoleon's battlefield surgeon, Baron Larrey, observed improved survival of injured soldiers left in the snow compared with those treated with warm blankets and hot drinks $[19,20]$. However, cold storage of organs without active supply of oxygen and nutrients is limited to the energetic reserves of liver grafts, which are depleted between 24 and $48 \mathrm{~h}$ of storage, as anaerobic glycolysis is the main metabolic pathway [21]. This leads slowly to intracellular acidosis, nucleotide depletion, and accumulation of purine metabolites, e.g., hypoxanthine $[22,23]$. The time an organ can sustain these conditions depends therefore on cooling to reduce metabolic activity and oxygen requirements and on the use of fluids designed to preserve the intracellular milieu in the absence of proper $\mathrm{Na}+\mathrm{K}+$ pump function [24]. In addition, metabolic function is more difficult to assess at temperatures below $15{ }^{\circ} \mathrm{C}$, especially for livers, where no active bile production is measurable in the cold [25].

In contrast, the concept of full physiological support of organs outside of the body under normothermic conditions aims to avoid metabolic stress, provides oxygen and energy by driving aerobic pathways, and allows testing of organ function [26-28]. Applying however normothermic perfusion after ischemia, e.g., normothermic regional perfusion (NRP) or normothermic ex vivo perfusion, bears also a risk of severe injury.

Ischemia reperfusion injury occurs when blood supply to a tissue is blocked for minutes to hours and afterwards restored [29]. The current consensus is that a period of ischemia primes the tissue for subsequent damage upon reperfusion [30]. While ischemic cells will die if blood flow is not reestablished, significant damage is initiated during reperfusion [31••]. Thus, paradoxically, the essential therapeutic intervention to treat ischemia, i.e., reperfusion, drives also tissue pathophysiology $[32 \cdot 0]$. Of note, the first minutes of reperfusion are most critical, as the first damaging and irreversible event is a burst of reactive oxygen species (ROS) produced by mitochondria [33••, 34]. Mitochondrial ROS initiate disrupting of adenosine triphosphate (ATP) production, opening of the mitochondrial permeability transition (MPT) pore, and releasing of danger-

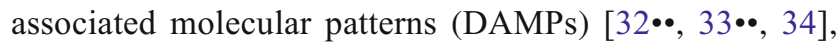
which lead to sterile inflammation (Fig. 1) [35•], besides activation of the innate immune system [36]. In the long term, such events trigger the formation of fibrotic scar tissue

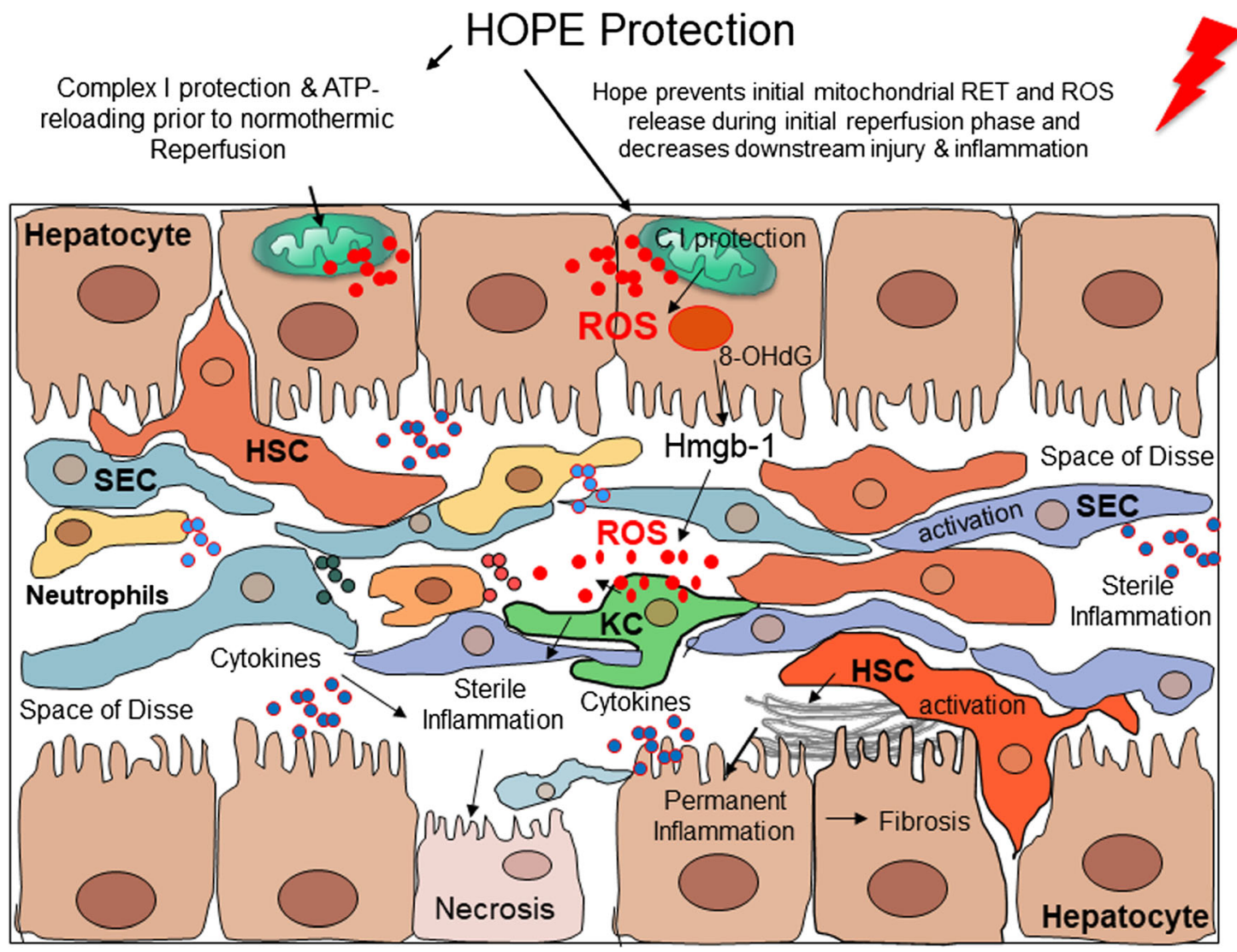

HOPE: Hypothermic Oxygenated Perfusion; ATP: Adenosine Triphosphate; ROS: Reactive Oxygen Species; 8-OHdG: Hydraxy-desoxyguanosin; DAMPs: Danger associated molecular pattern; HMGB-1: High-Mobility-Group-Box-Protein-1; HSC: Hepatic stellate cells; SEC: Sinusoidal endothelia cells; KC: Kupffer cells; PNF: Primary Non-Function;
Acute graft failure (PNF), Early necrosis

\section{Ongoing inflammation}

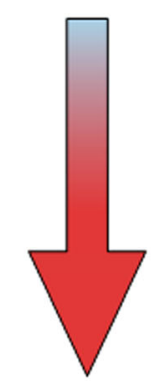

Chronic liver Injury and failure

(Biliary Injury \& Fibrosis)

Fig. 1 Mechanism of injury following ischemia/reperfusion and protection through hypothermic machine perfusion approaches 
replacing dead cells [37]. The exact causes of mitochondrial ROS upon reperfusion have been controversially discussed $[38,39]$, but recent studies support the view that complex I is the main site of mitochondrial superoxide production [33・•]. Metabolic transitions during ischemia shift electrons to succinate, which acts as an electron store in the absence of oxygen [31••]. Upon reperfusion, succinate fuels reverse electron transfer (RET) between complex II and I, due to high proton motive forces in the first minutes following ischemia [40]. Therapeutic interventions should therefore address accumulation of succinate during ischemia, or its oxidation during reperfusion. For example, inhibition of RET by temporarily blocking of complex II [34] or decreasing mitochondrial ROS by mitochondrial antioxidants is currently explored [41]. In this context, the supply of oxygen to ischemic mitochondria under cold conditions by hypothermic oxygenated organ perfusion is a new and interesting approach, as it addresses several key points:

In contrast to normothermic reperfusion, oxygenation of cells in the cold lead to a very limited ROS release, probably due to a low proton motive force at temperatures below $15^{\circ} \mathrm{C}$ (own data). Of note, reverse electron flow is mostly abundant in spite of accumulated succinate (own data). At the same time, forward metabolism of accumulated succinate leads to ATP resynthesis [34, 42]. The phenomenon of shutting down most fueling processes and supporting mitochondrial or chloroplast activity is probably related to a common ancestral process in animals, humans, and plants, enabling cells to survive in winter time by hibernation or winter rest [43, 44]. Reperfusion of ischemic livers, treated by cold oxygenated perfusion, triggers therefore significant less oxidative damage in mitochondria with subsequent less downstream inflammation (Fig. 1) [45, 46]. Importantly, mitochondrial switch from ischemic to fully ATP loaded status needs $1-2 \mathrm{~h}$ of cold oxygenated perfusion, which can be performed after cold storage in transplant centers [47]. Such end-ischemic treatment of livers is attractive and cheap, as it needs no additional theater capacity [48].

The disadvantage of this approach is the current lack of methods in testing the energetic status in perfused livers. It is also unclear how long cold oxygenated perfusion could be safely maintained [49••, 50]. Upcoming research, however, is awaited and analysis of perfusate during cold oxygenated perfusion by NMR techniques will likewise allow measuring metabolic function of livers during cold perfusion.

Importantly, the effectiveness of an end-ischemic cold liver oxygenation has been further paralleled by numerous studies from the group of Minor who performed oxygen persufflation in the livers and kidneys under hypothermic conditions [51]. Likewise, normothermic oxygenated shortterm perfusion provides also protection of the kidneys in spite of significant cold storage periods before end-ischemic perfusion $[52,53]$.
Different Technical Aspects of Hypothermic Liver Perfusion

The majority of experimental studies published on hypothermic machine perfusion (HMP) in the last 20 years involved mainly ex vivo liver perfusions without implantation [54]. In accordance with experiences from the kidney perfusions, HMP in livers was initially applied continuously and demonstrated improved hepatocyte and endothelial cell viability compared to simple cold storage [55-57]. The experimental conditions used, however, varied largely, and most of these studies were performed on liver grafts with no or only minor injury.

Regarding the perfusion route, two different approaches are competitively used. Single portal vein perfusion was usually preferred in rat livers [57-62], while seven studies explored liver integrity using dual perfusion techniques via hepatic artery and portal vein in pig livers [55, 56, 63-67]. Although dual perfusion through the hepatic artery and the portal vein failed to show clear advantages in ex vivo models $[55,64,66$, 68], advocates of this dual technique repeatedly emphasize better supply of oxygen to the peribiliary vascular plexus [69-71]. Most of the interlobular biliary branches are however also reached by portal branches, and the debate is ongoing regarding the amount of oxygen needed in the portal vein during HMP. In discarded human livers, Jomaa et al. showed feasibility of short and end-ischemic machine liver perfusion at $4-8{ }^{\circ} \mathrm{C}$ using dual vs single portal vein or hepatic artery [72]. No histologically difference appeared in these livers comparing different perfusion routes [72]. The technique of dual hypothermic machine liver perfusion has first been transferred into clinical practice by the group of James Guarrera, who reported outcomes of 20 human livers transplanted after dual HMP [73].

Next to the perfusion route, the temperature during HMP has been described at a wide range between 1 and $22{ }^{\circ} \mathrm{C}$ [74]. Metabolic activity appears more depressed at lower temperature, while the perfusate viscosity increases [75]. In this context, higher vascular resistances have been reported during HMP, which transmit an increased risk of endothelial injury in the liver sinusoids, which becomes more evident when cold perfusion is prolonged and high perfusion pressures are used $[60,76,77]$. Ex situ perfusion experiments are therefore limited to relatively short intervals between 2 and $24 \mathrm{~h} \mathrm{[74].} \mathrm{In}$ addition, high perfusion pressures were shown to induce endothelial and Kupffer cell injury and most professionals therefore perform HMP at low portal vein pressure of 3-5 $\mathrm{mmHg}$ and low arterial pressure of $20-30 \mathrm{mmHg}$ [78].

Tissue oxygenation during HMP simply relies on the dissolved oxygen in a blood-free perfusate [79], and the amount of oxygen needed in the perfusate is another matter of debate. Experimental studies have described a wide range of perfusate oxygenation between 10 and $106 \mathrm{kPA}$ [74, 80]. Importantly, 


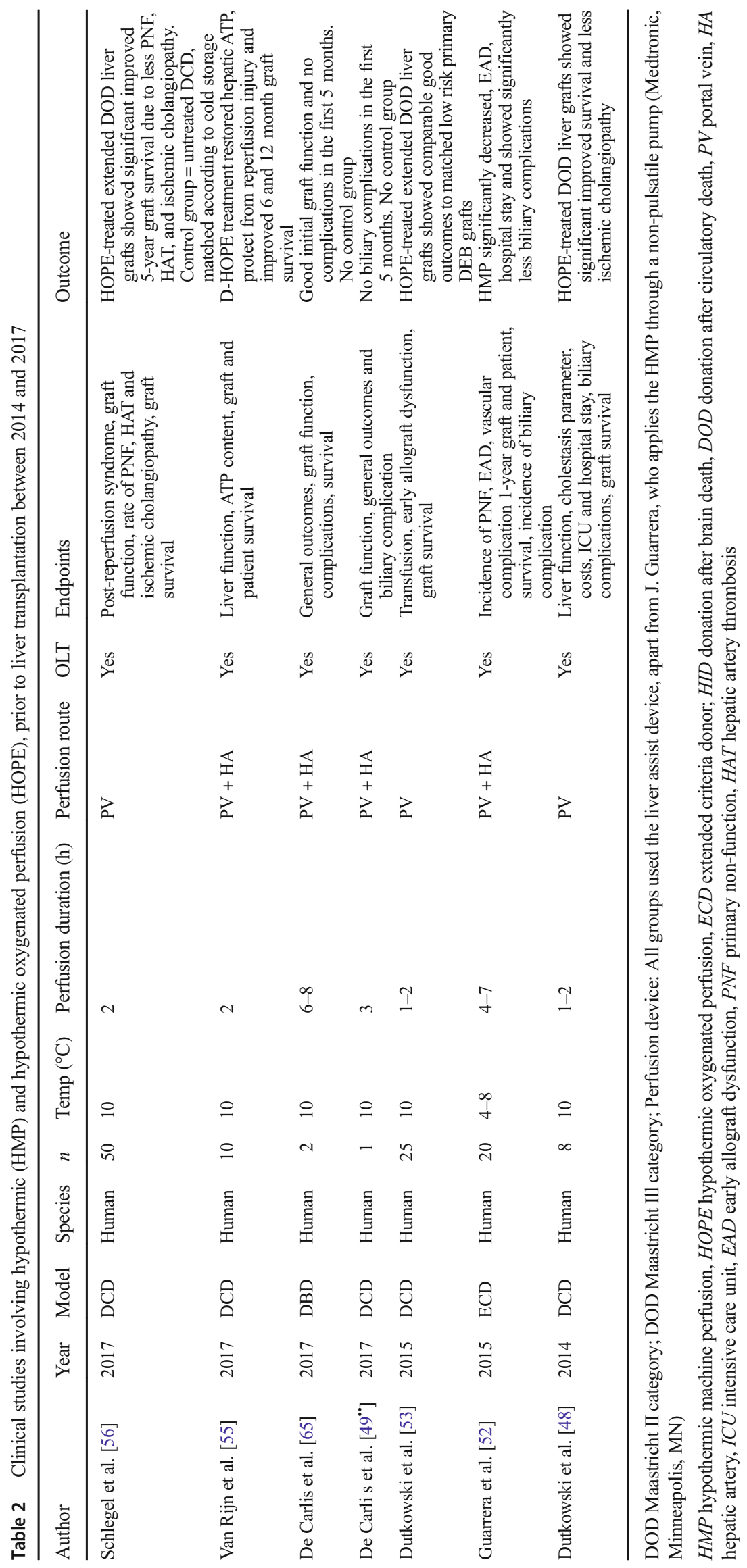


such cold oxygenation enables graft mitochondria to sufficiently produce and restore cellular energy, which increases significantly already within the first hour of perfusion [81-83]. Based on this, majority of centers, who apply HMP in liver transplantation, use it only for a short end-ischemic period $[78,84,85]$. Another advantage of HMP is the much easier technical approach because machine transport is not necessary.

Multiple perfusion solutions including Belzer UW solution and Vasosol with different variations were assessed in experimental studies [5, 74]. For example, low potassium concentrations were found to be protective and experimental studies showed a decreased vascular resistance of livers during cold perfusion [60]. Although several additives, i.e., reactive oxygen scavengers, vasodilators, and amino acids, have been assessed in experiments to improve perfusion quality of livers, none of these substances are routinely used in clinical practice yet [73].The majority of perfusion experiments has however been performed with Belzer UW machine perfusion solution [86]. Importantly, this UW perfusion solution is used for most liver perfusions today, despite the fact that this solution has initially been developed to perfuse kidneys and achieved CE certificate for this application.

\section{Clinical Applications}

Hypothermic dual (portal vein and hepatic artery) perfusion of twenty standard DBD human livers was first reported in 2010 by Guarerra et al. [73]. Machine perfusion was applied after previous 8-9 h cold storage and transport of organs to the recipient center. Prior to implantation, livers underwent 3$7 \mathrm{~h}$ HMP with relatively high flow rates of $0.667 \mathrm{ml} / \mathrm{g}$ liver weight/min. Importantly, no additional oxygen was supplemented into the perfusate and $\mathrm{pO}_{2}$ levels in perfusates ranged between 120 and $160 \mathrm{mmHg}$ [73]. The team of James
Guarrera performs the end-ischemic dual cold liver perfusion (cannulating portal vein and hepatic artery) using the modified Medtronic PBS device ${ }^{\circledR}$ (Medtronic Minneapolis). A Vasosol®-based perfusate, supplemented with vasodilators and antioxidants, is continuously circulated through the liver at temperatures between 4 and $8{ }^{\circ} \mathrm{C}$ [73]. Of note, the perfusion flows are adjusted to the liver weight $(0.667 \mathrm{ml}$ perfusate/ $\mathrm{g}$ liver/min) and perfusion pressures are monitored [73]. Perfusion resulted in significantly less peak enzyme release and shorter hospital stay, as well as less early allograft dysfunction (EAD) compared to a non-randomized control group. In a further report, the same investigators recently showed less biliary complications after hypothermic perfusion to marginal DBD organs (Table 2) [85].

Consistent to these results, hypothermic oxygenation perfusion (HOPE) has been shown to be effective in human DCD liver grafts, with less occurrence of intrahepatic biliary complications as compared to matched un-perfused DCD livers. Our practice of HOPE is based on more than 15 years of experimental research in several small and large animal transplant models [82, 87-89], as well as on human practice in DCD livers $[48,84]$. The perfusion is performed solely through the portal vein, in an open system (Liver Assist device (Organ Assist $\left.{ }^{\circledR}\right)$ ), where the liver swims in the cold perfusion solution and the perfusate flows out of the vena cava passively, to avoid sinusoidal congestion together with adjusting the maximum perfusion pressure at $3 \mathrm{mmHg}$ (Fig. 2) [82]. Under these conditions, the perfusion flow ranges between 150 and $250 \mathrm{ml} / \mathrm{min}[82,90]$. We perfuse with 31 of recirculating Belzer machine perfusion solution (MPS) at temperatures between 8 and $12{ }^{\circ} \mathrm{C}$ and a high oxygen saturation (60-80 kPa) [2]. Perfusion is maintained for at least $1 \mathrm{~h}$, but is generally performed during recipient hepatectomy until graft implantation without need of an extra theater setting.

Most importantly, HOPE treatment appears sufficient by single portal vein perfusion, as the entire intra- and a Human DCD liver

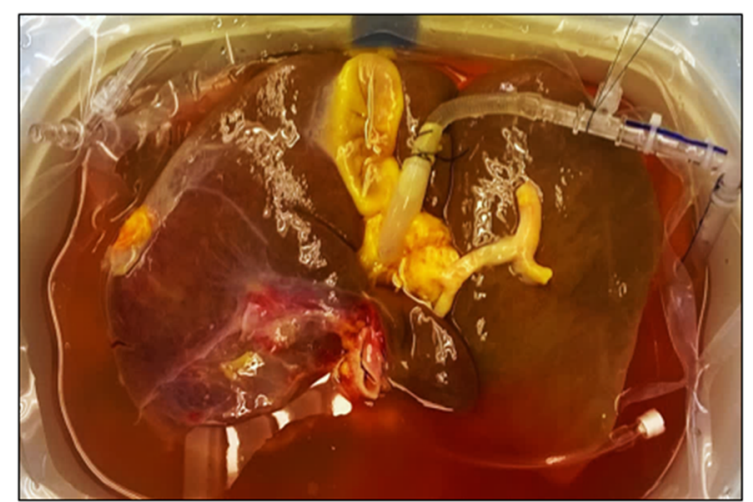

HOPE - perfusion of human DCD liver grafts: Pressure controlled perfusion (up to $3 \mathrm{mmHg}$ ) with 3 liter Belzer MPS with 60-80 $\mathrm{kPa}$ Oxygen through the portal vein, using the organ assist device

\section{b Human DCD liver with $40 \%$ macrosteatosis}

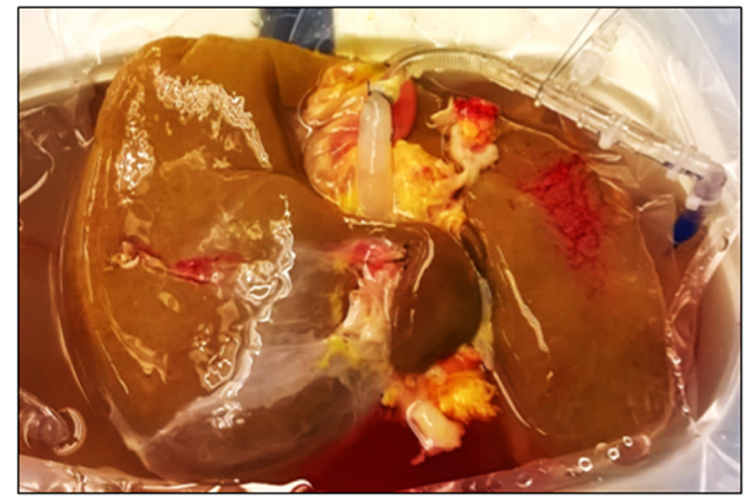

to implantation

Fig. 2 Examples of hypothermic oxygenated perfusion of liver grafts prior to implantation 
extrahepatic biliary system is positively effected through multiple collaterals between portal vein and hepatic artery $[48,84$, 91]. Furthermore, at hypothermic temperatures, single portal vein perfusion has been demonstrated to sufficiently protect the biliary tree, in spite of long donor warm ischemia times. The group from Groningen has reported the first ten extended DCD liver grafts, transplanted after dual HOPE (D-HOPE), where hypothermic oxygenated perfusion was applied through both hepatic artery and portal vein with subsequent transplantation. Importantly, no graft loss was described in the D-HOPE group compared to un-perfused controls (Table 2) [78]. The D-HOPE technique equals the HOPE technique and the team of R. Porte perfuses livers with the same liver assist device, using 41 of Belzer UW solution supplemented with glutathione and oxygen at partial pressures of at least $450 \mathrm{mmHg}$ [78]. End-ischemic cold perfusion in Groningen is performed at $10^{\circ}$ for at least $2 \mathrm{~h}$, and cannulation of the hepatic artery is achieved using a large supra-truncural aortic patch provided by the retrieval surgeon in order to not directly cannulate the hepatic artery to prevent arterial injury [78].

Randomized trials have been initiated to further evaluate the effect of HOPE on DBD and DCD liver grafts (hope-liver.com-Zurich, Groningen Institute for Organ transplantation-GIOT: University Hospital RWTH Aachen, Aachen, Germany). In the first long-term outcome analysis after HOPE, 50 recipients of extended DCD livers experienced a similar 5-year graft survival after HOPE treatment, when compared to lowest risk, primary DBD liver transplantations [92]. HOPE has also been recently applied in Maastricht type II DCD livers following standard NRP and cold storage in Italy [49"*] and the perfusion protected DCD kidneys, as demonstrated recently in a rodent model of kidney transplantation [93, 94].

\section{Conclusions and Future Perspective}

Improvement of the quality of liver grafts and prediction of organ function before implantation are the two main issues to allow the safe use of injured organs. Most efforts should therefore be directed to further develop dynamic preservation methods, which will likewise replace static cold storage in high-risk grafts. In this context, thresholds need to be defined, and machine perfusion techniques should be compared. For example, the impact of new perfusion devices, e.g., the Transmedics ${ }^{\circledR}$ machine for normothermic perfusion, is awaited [95], and potential new oxygen carriers, e.g., Hemopure ${ }^{\circledR}$ replacing RBCs during sub- and normothermic perfusion, are under investigation [96]. Importantly, modern analytical technologies (e.g., proteomics, metabolomics) are currently applied on liver tissue and perfusate and may help to explore new biomarkers, which are urgently needed to assess graft quality and predict not only the necessary perfusion duration but also liver function after subsequent transplantation.

\section{Compliance with Ethical Standards}

Conflict of Interest The authors declare that they have no conflict of interest.

Human and Animal Rights and Informed Consent This article does not contain any studies with human or animal subjects performed by any of the authors.

Open Access This article is distributed under the terms of the Creative Commons Attribution 4.0 International License (http:// creativecommons.org/licenses/by/4.0/), which permits use, duplication, adaptation, distribution and reproduction in any medium or format, as long as you give appropriate credit to the original author(s) and the source, provide a link to the Creative Commons license, and indicate if changes were made.

\section{References}

Papers of particular interest, published recently, have been highlighted as:

- Of importance

•- Of major importance

1.• Muller X, Marcon F, Sapisochin G, Marquez M, Dondero F, Rayar $M$, et al. Defining benchmarks in liver transplantation: a multicenter outcome analysis determining best achievable results. Ann Surg. 2017:Sep 6. First clinical study, where the best achievable outcomes after liver transplantation are defined.

2. Schlegel A, Kalisvaart M, Muiesan P. Machine perfusion in liver transplantation - an essential treatment or just an expensive toy? Minerva Anestesiol 2017.

3. Dutkowski P, De Rougemont $\mathrm{O}$, Clavien PA. Alexis Carrel: genius, innovator and ideologist. Am J Transplant. 2008;8(10): 1998-2003. https://doi.org/10.1111/j.1600-6143.2008.02364.x.

4. Belzer FO, Southard JH. Principles of solid-organ preservation by cold storage. Transplantation. 1988;45(4):673-6. https://doi.org/10. 1097/00007890-198804000-00001.

5. Graham JA, Guarrera JV. "Resuscitation" of marginal liver allografts for transplantation with machine perfusion technology. J Hepatol. 2014;61(2):418-31. https://doi.org/10.1016/j.jhep.2014. 04.019.

6. Harring TR, O'Mahony CA, Goss JA. Extended donors in liver transplantation. Clinics in Liver Disease. 2011;15(4):879-900. https://doi.org/10.1016/j.cld.2011.08.006.

7. Bruzzone P, Giannarelli D, Adam R. A preliminary european liver and intestine transplant association-european liver transplant registry study on informed recipient consent and extended criteria liver donation. Transplant Proc. 2013;45(7):2613-5. https://doi.org/10. 1016/j.transproceed.2013.07.024.

8. Easloffice@easloffice.eu. EA for the S of the LE address: EASL clinical practice guidelines: liver transplantation. J Hepatol. 2016;

9. Chu MJJ, Hickey AJR, Phillips ARJ, Bartlett ASJR. The impact of hepatic steatosis on hepatic ischemia-reperfusion injury in experimental studies: a systematic review. Biomed Res Int. 2013;2013:112. https://doi.org/10.1155/2013/192029.

10. Nemes B, Gámán G, Polak WG, Gelley F, Hara T, Ono S, et al. Extended criteria donors in liver transplantation Part I: reviewing the impact of determining factors. Expert Rev Gastroenterol $\{\&\}$ Hepatol. 2016;10(7):827-39. https://doi.org/10.1586/17474124. 2016.1149061 
11. Routh D, Naidu S, Sharma S, Ranjan P, Godara R. Changing pattern of donor selection criteria in deceased donor liver transplant: a review of literature. Journal of Clinical and Experimental Hepatology. 2013;3:337-46.

12. Calzadilla LB, Adams L. The natural course of non-alcoholic fatty liver disease. Int J Mol Sci. 2016;17(5):774. https://doi.org/10. 3390/ijms17050774.

13. Dasari B, Schlegel A, Mergental H, Perera T. The use of old donors in liver transplantation. Best Pr Res Clin Gastroenterol. 2017;31(2): 211-7. https://doi.org/10.1016/j.bpg.2017.03.002.

14. Jiménez-Romero C, Caso Maestro O, Cambra Molero F, Justo Alonso I, Alegre Torrado C, Manrique Municio A, et al. Using old liver grafts for liver transplantation: where are the limits? World J Gastroenterol. 2014;20:10691-702.

15. Dutkowski P, Schlegel A, Slankamenac K, Oberkofler CE, Adam $\mathrm{R}$, Burroughs $\mathrm{AK}$, et al. The use of fatty liver grafts in modern allocation systems: risk assessment by the balance of risk (BAR) score. Ann Surg. 2012;256(5):861-9. https://doi.org/10.1097/SLA. 0b013e318272dea2.

16. Bertuzzo VR, Cescon M, Odaldi F, Di Laudo M, Cucchetti A, Ravaioli M, et al. Actual risk of using very aged donors for unselected liver transplant candidates. Ann Surg. 2017;265(2):388-96. https://doi.org/10.1097/SLA.0000000000001681.

17. Quillin RCGJ. "In 10 years" of debate: pro-machine perfusion for liver preservation will be universal. Liver Transplant. 2016;22(S1): 25-8. https://doi.org/10.1002/lt.24630.

18. Schlegel A, Linecker M, Kron P, Györi G, De Oliveira ML, Müllhaupt B, et al. Risk assessment in high and low MELD liver transplantation. Am J Transplant. 2016;10:1-14.

19. Brewer LA 3rd, Dominique B, Larrey J. Father of modern military surgery, innovater, humanist. J Thorac Cardiovasc Surg. 1986;92(6):1096-8.

20. Crumplin MKH. The Myles Gibson military lecture: surgery in the Napoleonic Wars. J R Coll Surg Edinb. 2002;47:566-78.

21. Lockett CJ, Fuller BJ, Busza AL, Proctor E. Hypothermic perfusion preservation of liver: the role of phosphate in stimulating ATP synthesis studied by 31P NMR. Transpl Int. 1995;8(6):440-5. https:// doi.org/10.1111/j.1432-2277.1995.tb01553.x.

22. Fuller BJ, Lee CY. Hypothermic perfusion preservation: the future of organ preservation revisited? Cryobiology. 2007;54(2):129-45. https://doi.org/10.1016/j.cryobiol.2007.01.003.

23. Corps CL, Shires M, Crellin D, Smolenski R, Potts D, Pratt J, et al. Influence on energy kinetics and histology of different preservation solutions seen during cold ischemia in the liver. Transplant Proc. 2009;41(10):4088-93. https://doi.org/10.1016/j.transproceed.2009. 07.107 .

24. De Loecker R, Fuller BJ, Gruwez J, De Loecker W. The effects of cryopreservation on membrane integrity, membrane transport, and protein synthesis in rat hepatocytes. Cryobiology. 1990;27(2):14352. https://doi.org/10.1016/0011-2240(90)90006-P.

25. Curtis LR, Kemp CJSA. Biliary excretion of [14C]taurocholate by rainbow trout (Salmo gairdneri) is stimulated at warmer acclimation temperature. Comp Biochem Physiol C. 1986;84(1):87-90. https:// doi.org/10.1016/0742-8413(86)90170-2.

26. Ravikumar R, Jassem W, Mergental H, Heaton N, Mirza D, Perera MTPR, et al. Liver transplantation after ex vivo normothermic machine preservation: a phase 1 (first-in-man) clinical trial. Am J Transplant. 2016;16(6):1779-87. https://doi.org/10.1111/ajt.13708.

27. Ceresa C, D N SK, PJ F. Cold storage or normothermic perfusion for liver transplantation: probable application and indications. Curr Opin Organ Transpl. 2017;22(3):300-5. https://doi.org/10.1097/ MOT.0000000000000410.

28. Op Den Dries S, Karimian N, Sutton ME, Westerkamp AC, Nijsten MWN, Gouw ASH, et al. Ex vivo normothermic machine perfusion and viability testing of discarded human donor livers. Am J Transplant. 2013;13(5):1327-35. https://doi.org/10.1111/ajt.12187.
29. van Golen RF, Reiniers MJ, Vrisekoop N, Zuurbier CJ, Olthof PB, van Rheenen J, et al. The mechanisms and physiological relevance of glycocalyx degradation in hepatic ischemia/reperfusion injury. Antioxid Redox Signal. 2014;21(7):1098-118. https://doi.org/10. 1089/ars.2013.5751.

30. Reiniers MJ, van Golen RF, van Gulik TM, Heger M. Reactive oxygen and nitrogen species in steatotic hepatocytes: a molecular perspective on the pathophysiology of ischemia-reperfusion injury in the fatty liver. Antioxid Redox Signal. 2014;21(7):1119-42. https://doi.org/10.1089/ars.2013.5486.

31.• Chouchani ET, Pell VR, Gaude E, Aksentijević D, Sundier SY, Robb EL, et al. Ischaemic accumulation of succinate controls reperfusion injury through mitochondrial ROS. Nature. 2014;515(V): 431-5. This experimental study parallels underlying mechanism of ROS release by the mitochondrial chain in different organs.

32.• Chouchani ET, Pell VR, James AM, Work LM, Saeb-Parsy K, Frezza C, et al. A unifying mechanism for mitochondrial superoxide production during ischemia-reperfusion injury. Cell Metabolism. 2016;23:254-63. This study describes underlying mechanisms and sources of ROS release in mitochondria

33.• Murphy MP. How mitochondria produce reactive oxygen species. Biochem J 2009;417(1):1-13. This review focuses on ROS release from mitochondria, DOI: https://doi.org/10.1042/ BJ20081386.

34. Mills EL, Kelly B, Logan A, Costa ASH, Varma M, Bryant CE, et al. Succinate dehydrogenase supports metabolic repurposing of mitochondria to drive inflammatory macrophages. Cell. 2016;167(2): 457-470.e13. https://doi.org/10.1016/j.cell.2016.08.064.

35. van Golen RF, Reiniers MJ, Olthof PB, van Gulik TM HM. Sterile inflammation in hepatic ischemia/reperfusion injury: present concepts and potential therapeutics. J Gastroenterol Hepatol. 2013;3(28):394-400. This review describes downstream effects after normothermic reperfusion on immune cells.

36. Schlegel A, Kron P, Dutkowski P. Hypothermic oxygenated liver perfusion: basic mechanisms and clinical application. Curr Transplant Reports. 2015;2(1):52-62. https://doi.org/10.1007/ s40472-014-0046-1.

37. Tsuchida T, Friedman SL. Mechanisms of hepatic stellate cell activation. Nat Rev Gastroenterol Hepatol. 2017;14(7):397-411. https://doi.org/10.1038/nrgastro.2017.38.

38. Siebels I, Dröse S. Q-site inhibitor induced ROS production of mitochondrial complex II is attenuated by TCA cycle dicarboxylates. Biochim Biophys Acta Bioenerg. 2013;1827(10): 1156-64. https://doi.org/10.1016/j.bbabio.2013.06.005.

39. Dröse S, Brandt U, Wittig I. Mitochondrial respiratory chain complexes as sources and targets of thiol-based redox-regulation. Biochimica et Biophysica Acta - Proteins and Proteomics. 2014;1844(8):1344-54. https://doi.org/10.1016/j.bbapap.2014.02. 006.

40. Pell VR, Chouchani ET, Murphy MP, Brookes PS, Krieg T. Moving forwards by blocking back-flow the yin and yang of MI therapy. Circ Res. 2016;118:898-906.

41. Tauskela JS. Drug evaluation: MitoQ - a mitochondria-targeted antioxidant. Idrugs. 2007;10:399-412.

42. Kron P, Schlegel A, Mancina L, Clavien P, Dutkowski P. Hypothermic oxygenated perfusion (HOPE) for fatty liver grafts in rats and humans. J Hepatol. 2017;Sep 1.(pii: S01688278(17)32268-7. doi: https://doi.org/10.1016/j.jhep.2017.08. 028. [Epub ahead of print]).

43. Sharma P, Jha AB, Dubey RS, Pessarakli M. Reactive oxygen species, oxidative damage, and antioxidative defense mechanism in plants under stressful conditions. J Bot. 2012;2012:1-26. https:// doi.org/10.1155/2012/217037.

44. Brown JC, McClelland GB, Faure PA, Klaiman JM, Staples JF. Examining the mechanisms responsible for lower ROS release rates 
in liver mitochondria from the long-lived house sparrow (Passer domesticus) and big brown bat (Eptesicus fuscus) compared to the short-lived mouse (Mus musculus). Mech Ageing Dev. 2009;130(8):467-76. https://doi.org/10.1016/j.mad.2009.05.002.

45. Schlegel A, Kron P, Graf R, Dutkowski P, Clavien PA. Warm vs. cold perfusion techniques to rescue rodent liver grafts. J Hepatol. 2014;61(6):1267-75. https://doi.org/10.1016/j.jhep.2014.07.023.

46. Schlegel A, Graf R, Clavien PA, Dutkowski P. Hypothermic oxygenated perfusion (HOPE) protects from biliary injury in a rodent model of DCD liver transplantation. J Hepatol. 2013;59(5):984-91. https://doi.org/10.1016/j.jhep.2013.06.022.

47. Gallinat A, Efferz P, Paul A, Minor T. One or $4 \mathrm{~h}$ of "in-house" reconditioning by machine perfusion after cold storage improve reperfusion parameters in porcine kidneys. Transpl Int. 2014;27(11):1214-9. https://doi.org/10.1111/tri.12393.

48. Dutkowski P, Schlegel A, De Oliveira M, Müllhaupt B, Neff F, Clavien PA. HOPE for human liver grafts obtained from donors after cardiac death. J Hepatol. 2014;60(4):765-72. https://doi.org/ 10.1016/j.jhep.2013.11.023.

49.• De Carlis L, De Carlis R, Lauterio A, Di Sandro S, Ferla F, Zanierato M. Sequential use of normothermic regional perfusion and hypothermic machine perfusion in donation after cardiac death liver transplantation with extended warm ischemia time. Transplantation. 2016; Oct. This interesting case report describes the HOPE treatment and transplantation of a type II DCD liver after initial NRP in the donor.

50. Schlegel A, Dutkowski P. Role of hypothermic machine perfusion in liver transplantation. Transplant International. Blackwell Publishing Ltd. 2015;28:677-89.

51. Minor T, Paul A. Hypothermic reconditioning in organ transplantation. Current Opinion in Organ Transplantation. 2013;18(2):1617. https://doi.org/10.1097/MOT.0b013e32835e29de.

52. Hosgood SA, Van Heurn E, Nicholson ML. Normothermic machine perfusion of the kidney: better conditioning and repair? Transpl Int. 2015;28(6):657-64. https://doi.org/10.1111/tri.12319.

53. Hosgood SA. Renal transplantation after ex vivo normothermic perfusion: the first clinical study. Am J Transplant. 2013;13(5): 1246-52.

54. Schlegel A, Dutkowski P. Role of hypothermic machine perfusion in liver transplantation. Transpl Int. 2015;28(6):677-89. https://doi. org/10.1111/tri.12354.

55. Dirkes MC, Post ICJH, Heger M, Van Gulik TM. A novel oxygenated machine perfusion system for preservation of the liver. Artif Organs. 2013;37(8):719-24. https://doi.org/10.1111/aor.12071.

56. Vekemans K, Liu Q, Brassil J, Komuta M, Pirenne J, Monbaliu D. Influence of flow and addition of oxygen during porcine liver hypothermic machine perfusion. Transplant Proc. 2007;39(8):264751. https://doi.org/10.1016/j.transproceed.2007.08.007.

57. So PW, Fuller BJ. A comparison of the metabolic effects of continuous hypothermic perfusion or oxygenated persufflation during hypothermic storage of rat liver. Cryobiology. 2002;43(3):238-47.

58. Giannone FA, Treré D, Domenicali M, Grattagliano I, Baracca A, Sgarbi G, et al. An innovative hyperbaric hypothermic machine perfusion protects the liver from experimental preservation injury. Sci World J. 2012;2012:1-9. https://doi.org/10.1100/2012/573410.

59. T Hart NA, Van Der Plaats A, Leuvenink HGD, Van Goor H, Wiersema-Buist J, Verkerke GJ, et al. Hypothermic machine perfusion of the liver and the critical balance between perfusion pressures and endothelial injury. In: Transplantation Proceedings. 2005. p. $332-4$.

60. Jain S, Xu H, Duncan H, Jones JW, Zhang JX, Clemens MG, et al. Ex-vivo study of flow dynamics and endothelial cell structure during extended hypothermic machine perfusion preservation of livers. Cryobiology. 2004;48(3):322-32. https://doi.org/10.1016/j. cryobiol.2004.01.010.
61. Dutkowski P, Odermatt B, Heinrich T, Schönfeld S, Watzka M, Winkelbach V, et al. Hypothermic oscillating liver perfusion stimulates ATP synthesis prior to transplantation. J Surg Res. 1998;80(2):365-72.

62. Lüer B, Koetting M, Efferz P, Minor T. Role of oxygen during hypothermic machine perfusion preservation of the liver. Transpl Int. 2010;23(9):944-50.

63. Liu Q, Vekemans K, van Pelt J, Pirenne J, Himmelreich U, Heedfeld V, et al. Discriminate liver warm ischemic injury during hypothermic machine perfusion by proton magnetic resonance spectroscopy: a study in a porcine model. Transplant Proc. 2009;41(8):3383-6. https://doi.org/10.1016/j.transproceed.2009. 09.025 .

64. Monbaliu D, Vekemans K, De Vos R, Brassil J, Heedfeld V, Qiang $\mathrm{L}$, et al. Hemodynamic, biochemical, and morphological characteristics during preservation of normal porcine livers by hypothermic machine perfusion. Transplant Proc. 2007;39(8):2652-8. https:// doi.org/10.1016/j.transproceed.2007.08.009.

65. Van Der Plaats A, Maathuis MHJ, T Hart NA, Bellekom AA, Hofker HS, Van Der Houwen EB, et al. The Groningen hypothermic liver perfusion pump: functional evaluation of a new machine perfusion system. Ann Biomed Eng 2006;34(12):1924-34, DOI: https://doi.org/10.1007/s10439-006-9207-4.

66. Liu Q, Vekemans K, Iania L, Komuta M, Parkkinen J, Heedfeld V, et al. Assessing warm ischemic injury of pig livers at hypothermic machine perfusion. J Surg Res. 2014;186(1):379-89. https://doi. org/10.1016/j.jss.2013.07.034.

67. Jain S, Lee CY, Baicu S, Duncan H, Xu H, Jones JW, et al. Hepatic function in hypothermically stored porcine livers: comparison of hypothermic machine perfusion vs cold storage. In: Transplantation Proceedings. 2005. p. 340-1.

68. T Hart NA, Der VPA, Leuvenink HGD, Van Goor H, WiersemaBuist J, Verkerke GJ, et al. Determination of an adequate perfusion pressure for continuous dual vessel hypothermic machine perfusion of the rat liver. Transpl Int. 2007;20(4):343-52. https://doi.org/10. 1111/j.1432-2277.2006.00433.x.

69. Op Den Dries S, Sutton ME, Lisman T, Porte RJ. Protection of bile ducts in liver transplantation: looking beyond ischemia. Transplantation. 2011;92:373-9. https://doi.org/10.1097/TP. 0b013e318223a384.

70. Op Den Dries S, Westerkamp AC, Karimian N, Gouw ASH, Bruinsma BG, Markmann JF, et al. Injury to peribiliary glands and vascular plexus before liver transplantation predicts formation of non-anastomotic biliary strictures. J Hepatol. 2014;60(6):11729. https://doi.org/10.1016/j.jhep.2014.02.010.

71. Op Den Dries S, Sutton ME, Karimian N, De Boer MT, WiersemaBuist J, Gouw ASH, et al. Hypothermic oxygenated machine perfusion prevents arteriolonecrosis of the peribiliary plexus in pig livers donated after circulatory death. PLoS One 2014;9(2).

72. Jomaa A, Gurusamy K, Siriwardana PN, Claworthy I, Collier S, De Muylder P, et al. Does hypothermic machine perfusion of human donor livers affect risks of sinusoidal endothelial injury and microbial infection? A feasibility study assessing flow parameters, sterility, and sinusoidal endothelial ultrastructure. In: Transplantation Proceedings. 2013. p. 1677-81.

73. Guarrera JV, Henry SD, Samstein B, Odeh-Ramadan R, Kinkhabwala M, Goldstein MJ, et al. Hypothermic machine preservation in human liver transplantation: the first clinical series. Am J Transplant. 2010;10(2):372-81. https://doi.org/10.1111/j.16006143.2009.02932.x.

74. Selten J, Schlegel A, de Jonge J, Dutkowski P. Hypo- and normothermic perfusion of the liver: which way to go? Best Practice and Research: Clinical Gastroenterology. 2017;31(2):171-9. https://doi. org/10.1016/j.bpg.2017.04.001.

75. Manekeller S, Schuppius A, Stegemann J, Hirner A, Minor T. Role of perfusion medium, oxygen and rheology for endoplasmic 
reticulum stress-induced cell death after hypothermic machine preservation of the liver. Transpl Int. 2008;21(2):169-77.

76. Minor T, Manekeller S, Sioutis M, Dombrowski F. Endoplasmic and vascular surface activation during organ preservation: refining upon the benefits of machine perfusion. Am J Transplant. 2006;6(6):1355-66. https://doi.org/10.1111/j.1600-6143.2006. 01338.x.

77. Xu H, Lee CY, Clemens MG, Zhang JX. Pronlonged hypothermic machine perfusion preserves hepatocellular function but potentiates endothelial cell dysfunction in rat livers. Transplantation. 2004;77(11):1676-82. https://doi.org/10.1097/01.TP.0000129644. 23075.71.

78. Van Rijn R, Karimian N, Matton A, Burlage L, Wetserkamp A, Van den Berg A, et al. Dual hypothermic oxygenated machine perfusion in liver transplants donated after circulatory death. Br J Surg. 2017;Jun;104(7):907-17. https://doi.org/10.1002/bjs.10515.

79. Dutkowski P, De Rougemont O, Clavien PA. Machine perfusion for "marginal" liver grafts. Am J Transplant. 2008;8(5):917-24. https:// doi.org/10.1111/j.1600-6143.2008.02165.x.

80. Bessems M, Doorschodt BM, Kolkert JLP, Vetelainen RL, van Vliet AK, Vreeling H, et al. Preservation of steatotic livers: a comparison between cold storage and machine perfusion preservation. Liver Transplant. 2007;13(4):497-504. https://doi.org/10.1002/lt. 21039.

81. Vajdová K, Graf R, Clavien PA. ATP-supplies in the cold-preserved liver: a long-neglected factor of organ viability. Hepatology. 2002;36(6):1543-52. https://doi.org/10.1002/hep.1840360633.

82. Schlegel A, De RO, Graf R, Clavien PA, Dutkowski P. Protective mechanisms of end-ischemic cold machine perfusion in DCD liver grafts. J Hepatol. 2013;58(2):278-86. https://doi.org/10.1016/j. jhep.2012.10.004.

83. Stegemann J, Minor T. Energy charge restoration, mitochondrial protection and reversal of preservation induced liver injury by hypothermic oxygenation prior to reperfusion. Cryobiology. 2009;58(3):331-6. https://doi.org/10.1016/j.cryobiol.2009.03.003.

84. Dutkowski P, Polak WG, Muiesan P, Schlegel A, Verhoeven CJ, Scalera I, et al. First comparison of hypothermic oxygenated PErfusion versus static cold storage of human donation after cardiac death liver transplants: an international-matched case analysis. Ann Surg. 2015;262(5):764-71. https://doi.org/10.1097/SLA. 0000000000001473.

85. Guarrera JV, Henry SD, Samstein B, Reznik E, Musat C, Lukose TI, et al. Hypothermic machine preservation facilitates successful transplantation of "orphan" extended criteria donor livers. Am J Transplant. 2015;15(1):161-9. https://doi.org/10.1111/ajt.12958.
86. Belzer F, Ashby BS, Dunphy JE. 24-hour and 72-hour preservation of canine kidneys. Lancet. 1967;290(7515):536-9. https://doi.org/ 10.1016/S0140-6736(67)90498-9.

87. Schlegel A, Kron P, Graf R, Clavien P-A, Dutkowski P. Hypothermic oxygenated perfusion (HOPE) downregulates the immune response in a rat model of liver transplantation. Ann Surg. 2014;260(5):931-7-8-8. https://doi.org/10.1097/SLA. 0000000000000941 .

88. Dutkowski P, Graf R, Clavien PA. Rescue of the cold preserved rat liver by hypothermic oxygenated machine perfusion. Am J Transplant. 2006;6(5 I):903-12.

89. Dutkowski P, Schönfeld S, Odermatt B, Heinrich T, Junginger T. Rat liver preservation by hypothermic oscillating liver perfusion compared to simple cold storage. Cryobiology. 1998;36(1):61-70. https://doi.org/10.1006/cryo.1997.2066.

90. Schlegel A, Kron P, Dutkowski P. Hypothermic machine perfusion in liver transplantation. Curr Opin Organ Transplant. 2016;21(3): 308-14. https://doi.org/10.1097/MOT.0000000000000303.

91. Schlegel A, Kron P, De Oliveira ML, Clavien PA, Dutkowski P. Is single portal vein approach sufficient for hypothermic machine perfusion of DCD liver grafts? Journal of Hepatology. Elsevier. 2016;64:239-41.

92. Schlegel A, Xavier M, Perera T, Clavien Pi-A, Isaac J, Muiesan P, et al. 5-year experience in human extended DCD liver transplantation treated by hypothermic oxygenated perfusion (HOPE) before implantation. Liver Transplant. 2017;ILTS Abstr:1.

93. Kron P, Schlegel A, de Rougemont O, Oberkofler CE, Clavien P-A, Dutkowski P. Short, cool, and well oxygenated-HOPE for kidney transplantation in a rodent model. Ann Surg. 2016;264(5):815-22. https://doi.org/10.1097/SLA.0000000000001766.

94. Jochmans I, Akhtar MZ, Nasralla D, Kocabayoglu P, Boffa C, Kaisar M, et al. Past, present, and future of dynamic kidney and liver preservation and resuscitation. Am J Transplant. 2016;16(9): 2545-55. https://doi.org/10.1111/ajt.13778.

95. Dhital KK, Iyer A, Connellan M, Chew HC, Gao L, Doyle A, et al. Adult heart transplantation with distant procurement and ex-vivo preservation of donor hearts after circulatory death: a case series. Lancet. 2015;385(9987):2585-91. https://doi.org/10.1016/S01406736(15)60038-1.

96. Liu Q, Nassar A, Farias K, Buccini L, Mangino MJ, Baldwin W, et al. Comparing normothermic machine perfusion preservation with different perfusates on porcine livers from donors after circulatory death. Am J Transplant. 2016;16(3):794-807. https://doi.org/ 10.1111/ajt.13546. 